Desi Susilawati, Ni Nyoman Yuliati, \& Herawati Khotmi: Faktor-faktor yang .....

\title{
Faktor-Faktor Yang Mempengaruhi Penggunaan Informasi Akuntansi Pada Usaha Mikro Kecil Menengah (Survei Pada UMKM Di Kecamatan Aikmel Lombok Timur)
}

\author{
Desi Susilawati \\ Ni Nyoman Yuliati \\ Herawati Khotmi \\ Sekolah Tinggi Ilmu Ekonomi AMM Mataram
}

\begin{abstract}
This study aims to examine the effect of education level, business size, length of business, and the lead time of the company towards the use of accounting information on UMKM in Aikmel Sub-district of East Lombok. Therefore, this research variable consists of 4 (four) independent variables, namely education level (X1), business size (X2), business length (X3), and lead time of company (X4) and its dependent variable is the use of accounting information $(Y)$. The population in this study is all UMKM located in District Aikmel East Lombok recorded in the Department of Cooperatives and UKM East Lombok regency. The sample was taken using simple random sampling that is random sampling. The data were obtained by spreading 55 questionnaires to 55 respondents in Aikmel sub-district of East Lombok which then given to the owner, manager or staff who have the highest rank on the UMKM which is sampled. The data were analyzed using multiple linear regression which was processed using SPSS softwere to know the influence of factors together or one by one against the use of accounting information. The results of this study indicate that the variable level of education, size of business, length of business, and lead time of the company have a significant effect on the use of accounting information partially or simultaneously.
\end{abstract}

Keywords : UMKM, Level of education, size of business, length of business, lead time of company, use of accounting information

\section{Pendahuluan}

\section{Latar Belakang}

Usaha Mikro Kecil dan Menengah (UMKM) merupakan salah satu kegiatan ekonomi yang dilakukan oleh sebagian besar masyarakat di 
Indonesia. Perkembangan usaha kecil dan menengah di Indonesia tidak lepas dari berbagai macam masalah. Masalah umum yang dihadapi oleh pengusaha kecil dan menengah seperti keterbatasan modal kerja, kesulitan bahan baku, keterbatasan teknologi, sumber daya manusia dengan kalitas yang baik, informasi, dan pemasaran (Widianto, 2010). Lebih lanjut dijelaskan bahwa lemahnya usaha kecil di Indonesia disebabkan oleh kombinasi berbagai faktor, antara lain; keterbatasan sumber daya manusia, teknologi, modal dan informasi, tetapi juga kurangnya dukungan dari pemerintah dan kurangnya kemauan penguasha-pengusaha kecil dan menengah nasional untuk berorientasi global.

Pentingnya penerapan ilmu akuntansi dalam pengelolaan keuangan Usaha Mikro Kecil Menengah (UMKM) dinilai masih kurang dipahami oleh para pengusaha. Masih banyak pengusaha kecil yang belum melakukan pencatatan atas laporan keuangan usahanya dengan baik. Bahkan ada juga yang tidak melakukan pencatatan. Para pengusaha kecil dan menengah biasanya hanya mengerjakan pembukuan sebatas pencatatan pendapatan dan pengeluaran saja. Akibatnya, laba bersih perusahaan sulit diketahui sehingga pengajuan kredit ke Bank untuk modal usaha sulit diperoleh, dikarenakan sebagian besar dari pelaku UMKM memiilki keterbatasan untuk mengahasilkan laporan keuangan yang berkualitas. Selain pembukuan keuangan dan laporan yang baik, lamanya sebuah usaha telah berjalan juga turut menjadi pertimbangan pihak penanam modal dalam melakukan kerjasama.

Pentingnya beberapa faktor tersebut diatas telah diteliti oleh banyak pihak diantaranya: Wahyudi, (2009), Hasil penelitian menunjukkan, pendidikan manajer/pemilik, skala usaha, berpengaruh terhadap penggunaan informasi akuntansi pada UKM di Yogyakarta. Masa memimpin perusahaan, umur perusahaan, dan pelatihan akuntansi dan manajer/pemilik tidak berpengaruh terhada penggunaan informasi akuntansi pada UKM di Yogyakarta. Setyawan, (2012), hasil penelitian yang telah dilakukan, diperoleh bahwa pengalaman pemilik, dan tingkat pengetahuan akuntansi pemilik UKM di wilayah Depok, sebenarnya berada dalam kategori baik, sehingga seharusnya sudah dapat memenfaatkan informasi akuntansi dari usahanya untuk pengambilan berbagai keputusan pengelolaan dan pengembangan usahanya.

\section{Rumusan masalah}

1. Apakah jenjang pendidikan, ukuran usaha, lama usaha,dan masa memimpin perusahaan secara parsial dapat mempengaruhi penggunaan informasi akuntansi pada UMKM di Kecamatan Aikmel Lombok Timur? 
Desi Susilawati, Ni Nyoman Yuliati, \& Herawati Khotmi: Faktor-faktor yang .....

2. Apakah jenjang pendidikan, ukuran usaha, lama usaha, dan masa memimpin perusahaan secara simultan dapat mempengaruhi penggunaan informasi akuntansi pada UMKM di Kecamatan Aikmel Lombok Timur?

\section{Tujuan Penelitian}

Adapun tujuan didalam penelitian ini adalah sebagai berikut :

1. Untuk mengetahui apakah jenjang pendidikan, ukuran usaha, lama usaha, dan masa memimpin perusahaan secara parsial dapat mempengaruhi penggunaan informasi akuntansi pada UMKM di Kecamatan Aikmel Lombok Timur.

2. Untuk mengetahui apakah jenjang pendidikan, ukuran usaha, lama usaha, dan masa memimpin perusahaan secara simultan dapat mempengaruhi penggunaan informasi akuntansi pada UMKM di Kecamatan Aikmel Lombok Timur.

\section{Tinjauan Pustaka}

\section{Definisi Usaha Mikro Kecil Menengah (UMKM)}

Pada dasarnya terdapat beberapa definisi yang diolah beberapa instansi yang berbeda untuk memberikan definisi terkait dengan usaha mikro, kecil dan menengah. Berikut adalah definisi mengenai UMKM tersebut :

Definisi menurut Undang-Undang No. 20 Tahun 2008 tentang Usaha Mikro, Kecil dan menengah :

" Usaha mikro adalah usaha produktif milik orang perorangan dan atau badan usaha perorangan yang memenuhi criteria usaha mikro. Usaha kecil adalah usaha produktif yang berdiri sendiri yang dilakukan oleh perseorangan atau badan usaha bukan merupakan anak cabang perusahaan yang di miliki, dikuasai atau menjadi bagian baik langsung maupun tidak langsung dari usaha menengah atau besar yang memenuhi criteria usaha kecil. Usaha menengah adalah usaha ekonomi produktif yang berdiri sendiri yang dilakukan oleh orang perorangan atau badan usaha yang bukan merupakan anak perusahaan atau cabang perusahaan yang dimiliki, dikuasai atau menjadi baik bagian langsung maupun tidak langsung dengan usaha kecil atau usaha besar dengan jumlah kekayaan bersih atau hasil penjualan tahunan'.

Definisi menurut Kementrian Koperasi dan UMKM

"Usaha Kecil (UK), termasuk usaha Mikro (UMI), adalah entitas usaha yang mempunyai kekayaan bersih paling banyak Rp.200.000.000, tidak termasuk tanah dan bangunan tempat usaha dan memiliki penjualan 
tahunan paling banyak Rp.1.000.000.000. Sementara itu, Usaha Menengah (UM) merupakan entitas usaha milik warga Negara Indonesia yang memiliki kekayaan bersih lebih besar dari Rp.200.000.000 s.d Rp.10.000.000.000, tidak termasuk tanah dan bangunan". Definisi tentang UMKM menurut Bank Indonesia :

"Usaha kecil adalah usaha produktif milik warga Negara Indonesia, yang berbentuk badan usaha orang perorangan, badan usaha yang tidak berbadan hukum, atau badan usaha ynag berbadan hukum seperti koperasi; bukan merupakan anak perusahaan atau cabang yang dimiliki, dikuasai atau berafiliasi, baik langsung maupun tidak langsung dengan usaha menengah atau besar".

Berdasarkan definisi diatas dapat dikatakan bahwa usaha mikro, kecil dan menengah adalah usaha ekonomi yang produktif yang di gerakkan oleh orang perorangan, atau badan usaha namun dengan modal usaha tertentu dan keterbatasannya dalam mengembangkan usaha, serta bukan anak perusahaan atau afiliasi yang dimiliki atau dikuasai oleh perusahaan atau koperasi.

\section{Kriteria Usaha Mikro Kecil Menengah (UMKM)}

Dengan banyaknya definisi yang menjelaskan tentang pengertian Usaha Mikro Kecil Menengah (UMKM) maka menimbulkan banyaknya perbedaan persepsi dalam hal pengelompokan atau penggolongan UMKM. Oleh karena itu dalam penelitian kali ini yang digunakan oleh penulis adalah UndangUndang No. 20 Tahun 2008 sebagai dasar untuk penggolongan UMKM tersebut berdasarkan kriteria yang ada sebagai berikut :

1. Kriteria Usaha Mikro adalah sebagai berikut :

a. Memiliki kekayaan bersih paling banyak Rp. 50.000.000,00 (lima puluh juta rupiah) tidak termasuk tanah dan bangunan tempat usaha.

b. Memiliki hasil penjualan tahunan paling banyak Rp. 300.000.000,00 (tiga ratus juta rupiah); dan

c. Memiliki jumlah tenaga kerja tidak lebih dari 4 orang.

2. Kriteria Usaha Kecil adalah sebagai berikut:

a. Memiliki kekayaan bersih lebih dari Rp. 50.000.000,00 (lima puluh juta rupiah) sampai dengan paling banyak Rp. 500.000.000,00 (lima ratus juta rupiah) tidak termasuk tanah dan bangunan.

b. Memiliki penjualan tahunan lebih dari Rp. 300.000.000,00 (tiga ratus juta rupiah) sampai dengan paling banyak Rp. 2.500.000.000,00 (dua milyar lima ratus juta rupiah); dan

c. Memiliki jumlah tenaga kerja 5 s.d 19 orang.

3. Kriteria Usaha Menengah adalah sebagai berikut: 
a. Memiliki kekayaan bersih lebih dari Rp. 500.000.000,00 (lima ratus juta rupiah) sampai dengan paling banyak Rp. 10.000.000.000,00 (sepuluh milyar rupiah) tidak termasuk tanah dan bangunan tempat usaha.

b. Memiliki penjualan tahunan lebih dari Rp. 2.500.000.000,00 (dua milyar lima ratus juta rupiah) sampai dengan paling banyak Rp. $50.000 .000 .000,00$ (lima puluh milyar rupiah); dan

c. Memiliki jumlah tenaga kerja 20 s.d 99 orang.

\section{Informasi Akuntansi}

Menurut Belkaoi (2011 : 6) mendefinisikan informasi akuntansi sebagai informasi kuantitatif tentang entitas ekonomi yang bermanfaat untuk pengambilan keputusan ekonomi dan menentukan pilihan-pilihan diantara alternatif-alternatif tindakan. Penggunaan informasi akuntansi untuk perencanaan strategis, pengawasan manajemen dan pengawasan operasional. Pengguna informasi akuntansi untuk perencanaan strategis, pengawasan manajemen, dan pengawasan operasional.

Menurut Holmes dan Nichols dalam Grace (2003) mengklarifikasikan informasi akuntansi dalam tiga jenis yang berbeda menurut manfaatnya bagi pemakai, yaitu:

1. Statutory accounting information, merupakan informasi yang harus disiapkan sesuai dengan peraturan yang ada.

2. Bugetary information, yaitu informasi akuntansi yang disajikan dalam bentuk anggaran yang berguna bagi pihak internal dalam perencanaan, penilaian, dan pengambilan keputusan.

3. Additional accounting information, yaitu informasi akuntansi lain yang disiapkan perusahaan guna meningkatkan efektifitas pengambilan keputusan manajer.

Pengertian akuntansi menurut American Accounting Association (AAA) dalam Soemarso (2013:3), adalah proses mengidentifikasi, mengukur, dan melaporkan informasi ekonomi, untuk memungkinkan adanya penilaian dan keputusan yang jelas dan tegas bagi mereka yang menggunakan informasi tersebut.

Dari kedua pengertian diatas dapat ditarik kesimpulan bahwa akuntansi mengandung dua pengertian yakni ;

1. Kegiatan Akuntansi

Bahwa akuntansi merupakan proses yang terdiri dari identifikasi, pengukuran dan pelaporan informasi ekonomi.

2. Kegunaan Akuntansi 
Bahwa informasi ekonomi yang dihasilkan oleh akuntansi diharapkan berguna dalam penilaian dan pengambilan keputusan mengenai kesatuan usaha yang bersangkutan.

\section{Rerangka Konseptual}

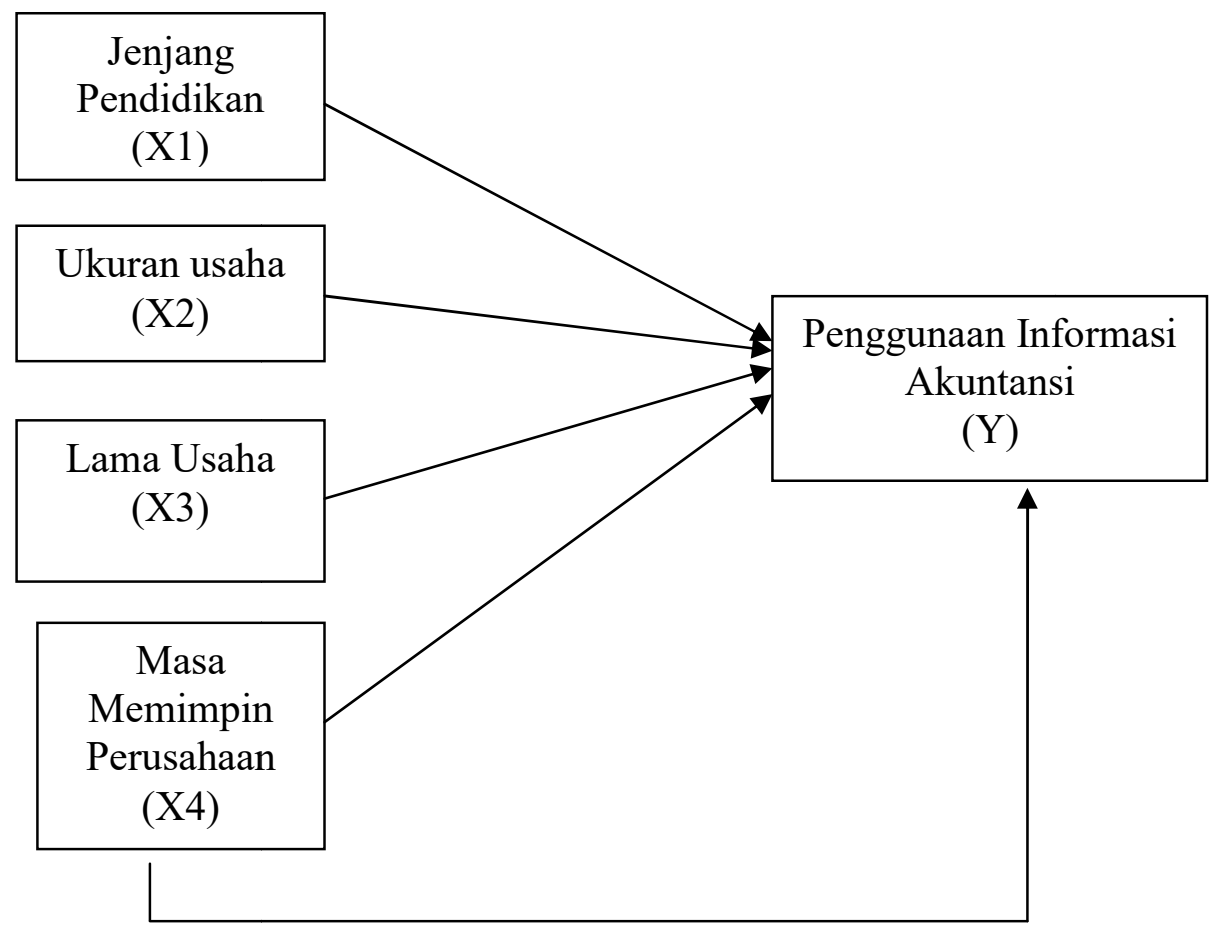

\section{Hipotesis}

$\mathrm{H}_{1}$ : Jenjang pendidikan berpengaruh terhadap penggunaan informasi akuntansi pada Usaha Mikro Kecil Menengah (UMKM).

$\mathrm{H}_{2}$ : Ukuran usaha berpengaruh terhadap penggunaan informasi akuntansi pada Usaha Mikro Kecil Menengah (UMKM).

$\mathrm{H}_{3}$ : Lamausaha berpengaruh terhadap penggunaan informasi akuntansipada Usaha Mikro Kecil Menengah (UMKM).

$\mathrm{H}_{4}$ : Masa memimpin perusahaan berpengaruh terhadap penggunaan informasi akuntansi pada Usaha Mikro Kecil Menengah (UMKM).

$\mathrm{H}_{5}$ : Jenjang pendidikan, ukuran usaha, lama usaha dan masa memimpin perusahaan secara bersama-sama berpengaruh terhadap penggunaan informasi akuntansi pada Usaha Mikro Kecil Menengah (UMKM). 
Desi Susilawati, Ni Nyoman Yuliati, \& Herawati Khotmi: Faktor-faktor yang .....

\section{Metode Penelitian}

\section{Jenis Penelitian}

Jenis penelitian yang digunakan dalam penelitian ini adalah penelitian asosiatif. Menurut Sugiyono (2012: 5) asosiatif yaitu penelitian yang digunakan untuk mengetahui hubungan antara dua variabel atau lebih. Dengan penelitian asosiatif ini maka akan dapat dibangun suatu teori yang dapat berfungsi untuk menjelaskan, meramalkan, dan mengontrol suatu gejala

\section{Teknik Pengumpulan Data}

Teknik pengumpulan data dalam penelitian ini menggunakan kuesioner yang diberikan kepada para pemilik UMKM di Kecamatan Aikmel Lombok Timur.

\section{Populasi dan Sampel}

Populasi dalam penelitian ini adalah seluruh UMKM yang terdaftar di Dinas Koperasi dan UKM Kabupaten Lombok Timur tahun 2016 sebanyak 124 UMKM. Penentuan sampel dalam penelitian ini menggunakan tekniksimple random sampling yaitu teknik pengambilan sampel secara acak tanpa memperhatikan strata yang ada dalam populasi tersebut.

\section{Jenis dan Sumber Data}

Jenis data yang digunakan dalam penelitian ini adalah data kuantitatif. Menurut Sugiyono (2014:92) Data kuantitatif yaitu nilai atau skor atas jawaban yang diberikan oleh responden terhadap pernyataan-pernyataan yang terdapat dalam kuesioner dan di ukur menggunakan skala likert.

Sumber data yang digunakan dalam penelitian ini adalah: (a) Data Primer, adalah data yang diperoleh dari sumber pertama baik dari individu dari perorangan seperti hasil angket (kuesioner) yang telah dijawab oleh responden kemudian dikumpulkan kembali oleh peneliti (Sekaran,2011), (b) Data sekunder merupakan data yang telah dikumpulkan oleh pihak lain dan dipublikasikan masyarakat pengguna data (Sugiyono,2012:129).

\section{Definisi Operasional Variabel Jenjang Pendidikan (X1)}

Jenjang pendidikan akan diukur berdasarkan pendidikan formal yang pernah diikuti sehingga pengukuran bersifat kontinyu. Pendidikan formal yang dimaksud adalah pendidikan yang diperoleh dibangku sekolah formal antara lain Sekolah Dasar (SD), Sekolah Menengah Pertama (SMP), Sekolah 
Menengah Umum (SMU) atau yang sederajat, Diploma (DIII), Sarjana (S1) dan Pasca Sarjana (S2)

\section{Ukuran Usaha (X2)}

Ukuran usaha diukur berdasarkan kemampuan perusahaan dalam mengelola usahanya dengan melihat berapa jumlah karyawan yang dipekerjakan, aktiva yang dimiliki, dan berapa besar pendapatan yang diperoleh perusahaan dalam satu periode akuntansi.

\section{Lama Usaha (X3)}

Lama usaha akan diukur berdasarkan umur perusahaan berdasarkan tahun sejak pendirian perusahaan sampai dengan penelitian ini dilakukan.

\section{Masa Memimpin Perusahaan (X4)}

Masa memimpin perusahaan akan diukur mulai dari manajemen tersebut penerima tanggungjawab sebagai pemilik atau manajer perusahaan sampai penelitian ini dilakukan.

\section{Penggunaan Informasi Akuntansi ( $Y$ )}

Pengukuran setiap dimensi variabel informasi akuntansi dilakukan dengan memberikan beberapa pertanyaan yang berhubungan dengan penggunaan informasi akuntansi dengan memberikan 4 poin untuk jawaban sangat setuju, 3 poin untuk jawaban setruju, 2 poin untuk jawaban tidak setuju, 1 poin utuk jawaban sangat tidak setuju.

\section{Analisis Data}

Teknik analisis data menggunakan regesi linier berganada digunakan untuk mendeteksi beberapa variabel yang berelasi dengan variabel yang diuji, untuk pengujian akan menggunakan model regresi linier berganda dengan bantuan program SPSS.

\section{Hasil Dan Pembahasan}

\section{Deskripsi Data Responden}

Populasi dari penelitian ini sebanyak 124 UMKM (Dinas Koperasi dan UKM Kabupaten Lombok Timur Tahun 2016). Populasi yang digunakan dalam penelitian ini adalah UMKM yang terdapat di Kecamatan Aikmel Lombok Timur. Teknik pengambilan sampel dalam penulisan ini adalah menggunakan metode simple random sampling.Pemilihan sampel secara simple random sampling dilakukan karena dalam metode sampel ini pengambilan sampel 
anggota populasi dilakukan secara acak tanpa memperhatikan strata yang ada dalam populasi itu (Margono 2004:126). Dengan demikian setiap unit sampling sebagai unsur populasi yang terpencil memperoleh peluang yang sama untuk mewakili populasi. Dengan menggunakan teknik sampel ini, maka sampel dari penelitian ini berjumlah 55 UMKM yang terdapat di Kecamatan Aikmel Lombok Timur. Adapun data yang penulis peroleh mengenai profil responden adalah sebagai berikut :

Tabel 1. Klasifikasi responden berdasarkan jenis kelamin

\begin{tabular}{|l|l|l|}
\hline Jenis Kelamin & Frekuensi & Persentase \\
\hline Laki-laki & 34 & $61,82 \%$ \\
\hline Perempuan & 21 & $38,18 \%$ \\
\hline Total & 55 & $100 \%$ \\
\hline
\end{tabular}

Sumber: data primer diolah 2017

Berdasarkan tabel 1 dapat dilihat bahwa dari 55 responden yang menjadi subjek penelitian, terlihat responden berjenis kelamin laki-laki lebih banyak daripada perempuan dengan jumlah $61,82 \%$ sedangkan perempuan dengan jumlah $38,18 \%$. Hal ini menggambarkan bahwa dari jumlah keseluruhan responden sebanyak 55 orang mayoritas pengusaha UMKM di Kecamatan Aikmel Lombok Timur berjenis kelamin laki-laki. Sehingga peran pengusaha UMKM laki-laki lebih dominan daripada pengusaha UMKM perempuan.

Tabel 2. Klasifikasi responden berdasarkan usia

\begin{tabular}{|l|l|l|}
\hline Usia & Frekuensi & Persentase \\
\hline $10-20$ tahun & 3 & $5,45 \%$ \\
\hline $21-30$ tahun & 16 & $29,09 \%$ \\
\hline $31-40$ tahun & 23 & $41,82 \%$ \\
\hline $41-50$ tahun & 7 & $12,73 \%$ \\
\hline$>50$ tahun & 6 & $10,91 \%$ \\
\hline Total & 55 & $100 \%$ \\
\hline
\end{tabular}

Sumber: data primer diolah 2017

Berdasarkan tabel 2 dapat dilihat bahwa dari 55 responden yang menjadi subjek penelitian, terlihat bahwa responden yang memiliki usia antara 31-40 tahun merupakan responden yang terbanyak dalam penelitian yaitu sebesar $41,82 \%$ sedangkan yang memiliki jumlah usia terendah yaitu 10-20 tahun yaitu sebesar 5,45\%. Hal ini menggambarkan bahwa dari jumlah keseluruhan responden sebanyak 55 orang mayoritas pengusaha UMKM di Kecamatan Aikmel Lombok Timur menduduki usia 31-40 tahun. Jumlah pengusaha UMKM usia rata-rata 31-40 tahun yang paling dominan dibandingkan dengan usia rata rata 10 - 20 tahun, 21-30 tahun, 41-50 
tahun, maupun usia > 50 tahun.Pengusaha UMKM yang berusia tua lebih berpengalaman, namun cenderung kurang berinovasi dibandingkan dengan pengusaha UMKM yang jauh lebih muda.

\section{Deskripsi Variabel penelitian}

Variabel Jenjang Pendidikan (X1)

Berikut disajikan dalam tabel 3 mengenai rekapitulasi tanggapan responden yang diajukan untuk mengukur variabel jenjang pendidikan melalui dimensi SMA/SMK, Strata 1, Strata 2, atau lainnya. Dimensi berikut ini frekuensi jenjang pendidikan terakhir pemilik UMKM :

Tabel 3. Kelompok responden berdasarkan jenjang pendidikan

\begin{tabular}{|l|l|l|}
\hline Jenjang Pendidikan & Frekuensi & Persentase \\
\hline SMA/SMK & 19 & $34,55 \%$ \\
\hline S1 & 26 & $47,27 \%$ \\
\hline S2 & 7 & $12,73 \%$ \\
\hline Lainnya & 10 & $18,18 \%$ \\
\hline Total & 55 & $100 \%$ \\
\hline
\end{tabular}

Sumber: data primer diolah 2017

Berdasarkan Tabel 3 dapat dilihat dari 55 responden yang menjadi subjek penelitian, terlihat bahwa yang memiliki jenjang pendidikan S1 merupakan responden terbanyak dalam penelitian yaitu sebesar $47,27 \%$, sedangkan yang memiliki jenjang pendidikan S2 merupakan responden terendah yaitu $12,73 \%$. Dari data tersebut juga dapat dilihat bahwa masih banyak pengusaha yang memiliki jenjang pendidikan SMA/SMK sederajat yaitu sebesar $18,18 \%$, dan pengusaha yang memiliki pendidikan dibawah SMA/SMK sederajat juga masih ada yang ditunjukkan pada kolom jenjang pendidikan lainnya sebesar $18,18 \%$. Hal ini menggambarkan bahwa dari jumlah keseluruhan responden sebanyak 55 orang mayoritas pengusaha UMKM di Kecamatan Aikmel Lombok Timur berpendidikan terakhir pada tingkat S1(strata 1). Jumlah pengusaha UMKM di tingkat pendidikan terakhir yang paling dominan adalah yang dari tingkat pendidikan terakhir S1 yang berjumlah 26 orang, dibandingkan dengan tingkat pendidikan terakhir S2, SMK dan lainnya. 


\section{Variabel Ukuran Usaha (X2)}

Variabel ukuran perusahaan terdiri dari 4 butir pertanyaan yang terbagi ke dalam 4 dimensi, yaitu dimensi asset terdiri dari 1 pertanyaan yaitu "asset usaha yang anda jalani berkisar?", dimensi jumlah karyawan terdiri dari satu pertanyaan yaitu "Berapakah jumlah karyawan yang anda miliki?", dimensi penjualan terdiri dari 1 pertanyaan yaitu "Berapakah nilai penjualan anda per tahunnya?", dan dimensi modal terdiri dari 1 pertanyaan yaitu "Berapakah modal usaha yang anda kelola?". Berikut ini akan disajikan dan dijelaskan kecendrungan jawab dari responden terhadap variable ukuran perusahaan dengan pendekatan distribusi frekuensi dan persentase:

\section{a. Aset}

Berikut disajikan dalam Tabel 4 mengenai rekapitulasi tanggpan responden yang diajukan untuk mengukur variabel ukuran perusahaan melalui dimensi asset.

Tabel 4. Kelompok responden berdasarkan asset

\begin{tabular}{|l|l|l|}
\hline Aset & Frekuensi & Persentase \\
\hline$<$ Rp. 10 juta & 10 & $18,18 \%$ \\
\hline Rp. 50 juta-Rp. 500 juta & 37 & $67,27 \%$ \\
\hline Rp. 500 juta-Rp. 10 Milyar & 8 & $15,55 \%$ \\
\hline >Rp. 10 milyar & 0 & $0,00 \%$ \\
\hline Total & 55 & $100 \%$ \\
\hline
\end{tabular}

Sumber: data primer diolah 2017

Berdasarkan tabel 4 dapat dilihat dari 55 responden yang menjadi subjek penelitian, terlihat bahwa yang memiliki asset Rp.50 juta-Rp500 juta merupakan responden terbanyak dalam penelitian yaitu sebesar $67,27 \%$, sedangkan yang memiliki asset Rp.500 juta- Rp.10 milyar merupakan responden terendah dalam penelitian ini yaitu sebesar $15,55 \%$. Hal ini menggambarkan bahwa dari jumlah keseluruhan responden sebanyak 55 orang mayoritas pengusaha UMKM di Kecamatan Aikmel Lombok Timur yang mempunyai asset Rp.50juta - Rp.500 juta.

\section{b. Jumlah Karyawan}

Berikut disajikan dalam tabel 5 mengenai rekapitulasi tanggapan responden yang diajukan untuk mengukur variabel ukuran perusahaan melalui dimensi jumlah karyawan. 
Tabel 5. Kelompok Responden Berdasarkan Jumlah Karyawan

\begin{tabular}{|l|l|l|}
\hline Jumlah Karyawan & Frekuensi & Persentase \\
\hline$<4$ orang & 19 & $34,55 \%$ \\
\hline $5-19$ orang & 32 & $58,18 \%$ \\
\hline $20-99$ orang & 4 & $7,27 \%$ \\
\hline$>100$ orang & 0 & $0,00 \%$ \\
\hline Jumlah & 55 & $100 \%$ \\
\hline
\end{tabular}

Sumber: data primer diolah 2017

Berdasarkan Tabel 5 dapat dilihat bahwa responden yang memiliki jumlah karyawan 5-19 orang merupakan responden terbanyak dalam penelitian ini yaitu 58,18\%, sedangkan yang memiliki jumlah karyawan 20-99 orang merupakan responden terendah dalam penelitian ini yaitu sebesar 7,55\%. Maka dapat diketahui bahwa rata-rata pengusaha UMKM di Kecamatan Aikmel Lombok Timur memiliki usaha kecil, karena rata-rata jumlah karyawannya kurang dari 20 orang.

\section{c. Penjualan (Tahunan)}

Berikut disajikan dalam Tabel 6 mengenai rekapitulasi tanggapan responden yang diajukan untuk mengukur variabel ukuran perusahaan melalui dimensi penjualan tahunan.

Tabel 6 Kelompok Responden Berdasarkan Penjualan

\begin{tabular}{|l|l|l|}
\hline Penjualan & Frekuensi & Persentase \\
\hline$<$ Rp 300 juta & 12 & $21,82 \%$ \\
\hline Rp 300 juta - Rp 2,5 milyar & 26 & $47,27 \%$ \\
\hline Rp 2,5 milyar - Rp 50 milyar & 17 & $30,91 \%$ \\
\hline$>$ Rp 50 milyar & 0 & $0,00 \%$ \\
\hline Jumlah & 55 & $100 \%$ \\
\hline
\end{tabular}

Sumber: data primer diolah 2017

Berdasarkan Tabel 6 dapat dilihat bahwa responden yang memiliki penjualan Rp 300 juta - Rp 2,5 milyar merupakan responden terbanyak dalam penelitian yaitu sebesar $47,27 \%$ sedangkan yang memiliki penjualan < Rp 300 juta merupakan responden terendah dalam penelitian ini yaitu sebesar 21,82\%. Maka dapat diketahui bahwa rata-rata pengusaha UMKM di Kecamatan Aikmel Lombok Timur memiliki penghasilan menengah keatas, karena rata-rata jumlah penjualan tahunan Rp300 juta - Rp2,5 milyar. 
Desi Susilawati, Ni Nyoman Yuliati, \& Herawati Khotmi: Faktor-faktor yang .....

\section{d. Modal Usaha}

Berikut disajikan dalam Tabel 7 mengenai rekapitulasi tanggapan responden yang diajukan untuk mengukur variabel ukuran usaha perusahaan melalui dimensi modal usaha.

Tabel 7. Kelompok Responden Berdasarkan Modal Usaha

\begin{tabular}{|l|l|l|}
\hline Modal & Frekuensi & Persentase \\
\hline$<$ Rp 10 juta & 9 & $16,36 \%$ \\
\hline Rp 10 juta - Rp 100 juta & 20 & $36.36 \%$ \\
\hline $\begin{array}{l}\text { Rp 100 juta - Rp 500 } \\
\text { juta }\end{array}$ & 21 & $38,18 \%$ \\
\hline$>$ Rp 500 juta & 5 & $9,09 \%$ \\
\hline Jumlah & 55 & $100 \%$ \\
\hline
\end{tabular}

Sumber: data primer diolah 2017

Berdasarkan Tabel 7 dari 55 responden terlihat bahwa, usaha yang memilki modal Rp 100 juta - Rp 500 juta merupakan usaha yang paling banyak dengan jumlah $38,18 \%$ dari seluruh sampel yang diambil, sedangkan usaha yang memiliki modal terkecil yaitu Rp $<10$ juta hanya 9 dari 55 responden yang diambil. Maka dapat diketahui bahwa rata-rata pengusaha UMKM di Kecamatan Aikmel Lombok Timur memiliki skala usaha kecil, karena rata-rata jumlah modal usaha Rp 100 juta - Rp 500 juta.

\section{4..2.3 Variabel Lama Usaha (X3)}

Variabel lama usaha terdiri dari 1 butir pertanyaan yang terbagi ke dalam 1 dimensi, yaitu dimensi lamanya usha berjalan terdiri dari 1 pertanyaan yaitu "Berapa lama usaha ini anda jalankan?". Berikut ini akan disajikan dan dijelaskan kecendrungan jawaban dari responden terhadap variable lama usaha dengan pendekatan distribusi frekuensi dan persentase. Berikut disajikan dalam Tabel 4.8 mengenai rekapitulasi tanggapan responaden yang diajukan untuk mengukur variabel ukuran perusahaan melalui dimensi lamanya uasaha berjalan. Hasil angket tentang lama usaha ditampilkan pada tabel berikut:

Tabel 8. Kelompok Usaha Berdasarkan Lama Usaha

\begin{tabular}{|l|l|l|}
\hline Lama Usaha Berjalan & Frekuensi & Persentase \\
\hline$<5$ tahun & 11 & $20 \%$ \\
\hline $6-10$ tahun & 22 & $40 \%$ \\
\hline $10-15$ tahun & 20 & $36,36 \%$ \\
\hline$>15$ tahun & 2 & $3,64 \%$ \\
\hline Jumlah & 55 & $100 \%$ \\
\hline
\end{tabular}

Sumber: data primer diolah 2017 
Berdasarkan Tabel 8 dapat dilihat bahwa responden yang memiliki lama usaha 6-10 tahun merupakan responden terbanyak dalam penelitian yaitu sebesar $40 \%$, sedangkan yang memiliki lama usaha $>15$ tahun merupakan responden terendah dalam penelitian ini yaitu sebesar 3,64\%. Maka dapat diketahui bahwa rata-rata pengusaha UMKM di Kecamatan Aikmel cukup memiliki pengalaman dalam mengelola usahanya. Karena suatau perusahaan yang dapat bertahan pada usaha yang sama dalam kurun waktu 6-10 tahun menggambarkan bahwa para pengusaha semakin memperoleh pembelajaran dalam mengelola perusahaan dan menggambarkan bahwa usahanyapun semakin berkembang.

\section{Variabel Masa Memimpin Perusahaan (X4)}

Variabel masa memimpin perusahaan terdiri dari 1 butir pertanyaan yang terbagi dalam 1 dimensi, yaitu dimensi lamanya seorang manajer memimpin perusahaan terdiri dari 1 pertanyaan yaitu "Berapa lama Bapak/Ibu menjabat sebagai manajer/pemilik perusahaan?". Berikut ini akan disajikan dan dijelaskan kecendrungan jawaban responden terhadap variable masa memimpin perusahaan dengan pendekatan distribusai frekuensi dan persentase.

Berikut disajikan dalam Tabel 9 mengenai rekapitulasi tanggapan responden yang diajukann untuk mengukur variabel masa memimpin perusahaan melalui dimensi berapa lama seorang menjabat sebagai manajer/pemilik perusahaan. Hasil angket tentang masa memimpin perusahaan ditampilkan pada tabel sebagai berikut:

Tabel 9. Kelompok Responden Berdasarkan Masa Memimpn Perusahaan

\begin{tabular}{|l|l|l|}
\hline Masa Memimpin Perusahaan & Frekuensi & Persentase \\
\hline$<5$ tahun & 9 & $16,36 \%$ \\
\hline $6-10$ tahun & 21 & $38,10 \%$ \\
\hline $10-15$ tahun & 23 & $41,82 \%$ \\
\hline$>15$ tahun & 2 & $3,64 \%$ \\
\hline Jumlah & 55 & $100 \%$ \\
\hline
\end{tabular}

Sumber: data primer diolah 2017

Berdasarkan Tabel 9 dapat dilihat bahwa responden yang masa memimpin perusahaan 10 - 15 tahun merupakan responden terbanyak dalam penelitian yaitu sebesar $41,82 \%$, sedangkan yang masa memimpin perusahaan $>15$ tahun merupakan responden terendah dalam penelitian ini yaitu sebesar 3,64\%. Hal ini menunjukkan bahwa rata-rata pengusaha UMKM di Kecamatan Aikmel Lombok Timur memiliki pengalaman mengelola usahanya. Karena seorang manajer/pemilik yang sudah lama memimpin 
Desi Susilawati, Ni Nyoman Yuliati, \& Herawati Khotmi: Faktor-faktor yang .....

perusahaan akan lebih berpengalaman tentang informasi akuntansi dan memperoleh pembelajaran dalam mengelola perusahaan dengan baik.

\section{Variabel Penggunaan Informasi akuntansi $(Y)$}

Variabel penggunaan informasi akuntansi terdiri dari 13 butir pernyataan yang terbagi ke dalam 1 dimensi, yaitu dimensi persepsi pengusaha terkait pentingnya pelaporan keuangan terdiri dari 13 pernyataan. Berikut ini akan disajikan dan dijelaskan kecendrungan jawaban dari responden terhadap variabel penggunaan informasi akuntansi dengan pendekatan distribusi frekuensi dan persentase.

Berdasarkan Tabel L.4 (lampiran 4) diketahui bahwa nilai persentase total skor tanggapan responden yang di peroleh dari pernyataan-pernyataan yang membentuk dimensi persepsi pengusaha terkait pentingnya pelaporan keuangan adalah sebesar $83,72 \%$ dengan mean skor $4,18 \%$ termasuk dalam kategori baik.

\section{Hasil Kualitas Data}

Hasil uji validitas diketahui bahwa semua indikatoryang digunakan untuk mengukur variabel-variabel yang digunakan dalam penelitian ini mempunyai koefisien korelasi yang lebih besar dari standar koefisien korelasi yaitu = 0,30 . Sehingga masing-masing item dari semua variabel dalam penelitian ini adalah valid.

Hasil uji reliabilitas diketahui bahwa nilai alpha masing-masing vaiabel penelitian memiliki nilai yang lebih besar dibandingkan dengan 0,60 sehingga disimpulkan semua variabel penelitian bersifat reliabel.

\section{Hasil Uji Asumsi Klasik}

Uji normalitas dalam penelitian ini menggunakan teknik One Sample Kolmogorof-Smirnov Test. Berdasarkan uji normalitas dengan hasil menunjukkan bahwa nilai signifikasi sebesar 0,200 > 0,05, maka asumsi normalitas tersebut terpenuhi, hal ini menunjukkan bahwa model regresi layak dipakai karena memenuhi asumsi normalitas atas data berdistribusi normal.

Uji multikolinearitas dilakukan dengan melihat nilai tolerance atau nilai VIF. Pada uji multikolinearitas menunjukkan bahwa tidak ada nilai toleransi yang kurang dari 0,1 dan nilai VIF yang lebih dari 10, sehingga dapat disimpulkan tidak terjadi multikolineartas untuk model persamaan regresi yang digunakan.

Pengujian heteroskedastisitas dalam penelitian ini menggunakan. diketahui bahwa $\mathrm{t}$ hitung berada pada $-\mathrm{t}_{\text {tabel }}<\mathrm{t}$ hitung $<\mathrm{t}$ tabel, yaitu $-0,986$, 
$0,027,1,134$, dan $-0,932$, sedangkan $t$ tabel dengan $\mathrm{df}=53$ adalah sebesar 2,006, maka $h_{0}$ diterima artinya pengujian antara variabel independen dengan variabel dependen tidak ada gejala heteroskedastisitas.

\section{Analisis Regresi}

Model statistik yang digunakan untuk menguji hipotesis digunakan analisis regresi linier berganda. Dengan persamaan regresi yang didapatkan adalah sebagai berikut :

$$
Y=0,290+0,305 X_{1}+0,349 X_{2}+0,123 X_{3}+0,079 X_{4}+e
$$

Keterangan :

$\mathrm{Y} \quad=$ Penggunaan Informasi Akuntansi

a $\quad=$ Konstanta

$b_{1} \quad=$ Koefisien Regresi Jenjang Pendidikan

$\mathrm{b}_{2} \quad=$ Koefisien Regresi Ukuran Usaha

$b_{3} \quad=$ Koefisien Regresi Lama Usaha

$\mathrm{b}_{4} \quad=$ Koefisien Regresi Masa Memimpin Perusahaan

$\mathrm{X}_{1} \quad=$ Jenjang Pendidikan

$\mathrm{X}_{2}=$ Ukuran Usaha

$\mathrm{X}_{3} \quad$ = Lama Usaha

$\mathrm{X}_{4} \quad=$ Masa Memimpin Perusahaan

e $\quad=$ Standar eror

\section{Uji Model}

Uji koefisisen determinasi $\left(R^{2}\right)$ adalah uji yang digunakan untuk mengetahui besaran dalam persen pengaruh variabel independen secara keseluruhan terhadap variabel dependen. Di ketahui nilai Adjusted $R$ Square adalah sebesar 0,331 (33,1\%). Hal ini berarti kemampuan variabel independen dalam menjelaskan variasi variabel dependen masih terbatas. Sedangkan sisanya yaitu sebesar 0,669 $(66,9 \%)$ merupakan hubungan dari variabel-variabel lain yang tidak dimasukkan kedalam penelitian.

\section{Uji Simultan (f-test)}

ANOVA $^{a}$

\section{Tabel 10. Hasil Uji f (Simultan)}

\begin{tabular}{|ll|l|l|l|l|l|}
\hline \multicolumn{2}{|c|}{ Model } & $\begin{array}{l}\text { Sum of } \\
\text { Squares }\end{array}$ & Df & $\begin{array}{l}\text { Mean } \\
\text { Square }\end{array}$ & F & Sig. \\
\hline 1 & Regression & 3.184 & 4 & .796 & 54.445 & $.000^{\mathrm{b}}$ \\
& Residual & .731 & 50 & .015 & & \\
& Total & 3.914 & 54 & & & \\
\hline
\end{tabular}


Berdasarkan hasil pengujian hipotesis (uji f) pada tabel 10 diatas, tampak bahwa nilai $\mathrm{F}$ hitung sebesar 54.445 mempunyai probabilitas (sig) 0,000 . Nilai sig ini lebih kecil dari nilai a $(0,000<0,05)$, maka dapat disimpulkan bahwa secara bersama-sama atau secara simultan variabel independen yaitu berpengaruh secara signifikan terhadap variabel dependen yaitu penggunaan informasi akuntansi $(Y)$.

Uji Parsial (t-test)

Tabel 11. Hasil Uji t (Parsial)

\begin{tabular}{|c|c|c|c|c|c|}
\hline \multirow[b]{2}{*}{ Model } & \multicolumn{2}{|c|}{$\begin{array}{l}\text { Unstandardized } \\
\text { Coefficients }\end{array}$} & \multirow{2}{*}{\begin{tabular}{|l|}
$\begin{array}{l}\text { Standardized } \\
\text { Coefficients }\end{array}$ \\
Beta \\
\end{tabular}} & \multirow[b]{2}{*}{$\mathrm{T}$} & \multirow[b]{2}{*}{ Sig. } \\
\hline & B & $\begin{array}{l}\text { Std. } \\
\text { Error }\end{array}$ & & & \\
\hline 1 (Constant) & .290 & .142 & & 30.273 & 0 \\
\hline $\mathrm{X} 1$ & .305 & .053 & .087 & 5.81 & .001 \\
\hline $\mathrm{X} 2$ & .349 & .048 & .109 & 7.255 & 0 \\
\hline X3 & .123 & .046 & .037 & 2.674 & .016 \\
\hline $\mathrm{X} 4$ & .079 & .032 & .231 & 2.466 & .028 \\
\hline
\end{tabular}

\section{Pembahasan}

\section{Pengaruh Jenjang Pendidikan Terhadap Penggunaan Informasi} Akuntansi Pada UMKM

Dari hasil perbandingan nilai $t$ terlihat bahwa $t_{\text {hitung }}>t_{\text {tabel, }}$ yaitu $\quad 5,810$ $>$ 2,009. Berdasarkan hasil uji $t$ (parsial) pada model regresi dapat disimpulkan bahwa $\mathrm{H}_{01}$ ditolak $\mathrm{H}_{\mathrm{a} 1}$ diterima, artinya secara parsial variabel jenjang pendidikan berpengaruh secara signifikan terhadap variabel penggunaan informasi akuntansi. Hasil penelitian ini didukung oleh hasil penelitian sebelumnya yaitu penelitian yang dilakukan oleh Wahyudi (2009), Murniati (2002), dan Grece (2003) yang menunjukakan hasil bahwa jenjang pendidikan berpengaruh secara signifikan terhadap penggunaaan informasi akuntansi.

\section{Pengaruh Ukuran Usaha Terhadap Penggunaan Informasi Akuntansi Pada UMKM}

Dari hasil perbandingan uji $\mathrm{t}$ yang dilakukan terlihat bahwa $t_{\text {hitung }}$ $>t_{\text {tabel, }}$ yaitu $7,255>2,009$. Berdasarkan uji t (parsial) pada model regresi 
dapat disimpulkan bahwa $\mathrm{H}_{02}$ ditolak $\mathrm{H}_{\mathrm{a} 2}$ diterima, artinya secara parsial variabel ukuran usaha berpengaruh secara signifikan terhadap variabel penggunaan informasi akuntansi. Hasil penelitian ini bertolak belakang dengan hasil penelitian sebelumnya seperti yang dilakukan oleh Grece (2003) yang menunjukkan hasil bahwa skala usha tidak berpengaruh terhadap penggunaan informasi akuntansi. Namun hasil penelitian ini didukung oleh hasil penelitian yang dilakukan oleh Wahyudi (2009) dan Murniati (2002) yang menunjukkan hasil bahwa skala usaha berpengaruh terhadap penggunaan informasi akuntansi.

\section{Pengaruh Lama Usaha Terhadap Penggunaan Informasi Akuntansi Pada UMKM}

Dari hasil perbandingan uji $t$ yang dilakukan terlihat bahwa $t_{\text {hitung }}>t_{\text {tabel, }}$ yaitu 2,674 $>2,009$. Berdasarkan hasil uji t (parsial) pada model regresi disimpulkan bahwa $\mathrm{H}_{03}$ ditolak atau $\mathrm{H}_{\mathrm{a} 3}$ diterima, artinya secara parsial variabel lama usaha berpengaruh secara signifikan terhadap variabel penggunaan informasi akuntansi. Hasil penelitian ini didukung oleh penelitian yang dilakukan oleh Grece (2003) dan Murniati (2002) yang menunjukkan hasil bahwa umur perusahaan berpengaruh terhadap penggunaan informasi akuntansi.

\section{Pengaruh Masa Memimpin Perusahaan Terhadap Penggunaan Informasi Akuntansi Pada UMKM}

Berdasarkan hasil uji t (parsial) pada model regresi, diperoleh nilai signifikasi variabel masa memimpin perusahaan sebesar 0,028 0,05 (taraf nyata signifikansi penelitian). Selain itu juga dari hasil perbandingan antara $t_{\text {hitung }}$ dan $t_{\text {tabel }}$ yang menunjukkan nilai $t_{\text {hitung }}$ sebesar 2,466 , sedangkan $t_{\text {tabel }}$ sebesar 2,009 .dari hasil tersebut terlihat bahwa $t_{\text {hitung }}>t_{\text {tabel }}$ yaitu $2.466>$ 0,009maka dapat disimpulkan bahwa $\mathrm{H}_{04}$ ditolak atau $\mathrm{H}_{\mathrm{a} 4}$ diterima, artinya secara parsial variabel masa memimpin perusahaan berpengaruh secara signifikan terhadap variabel penggunaan informasi akuntansi.

\section{Simpulan Dan Saran}

\section{Simpulan}

Berdasarkan hasil analisis data dan pembahasan yang telah diuraikan sebelumnya, maka dapat dikemukakan beberapa simpulan sebagai berikut :

1. Berdasarkan hasil uji parsial (uji t) melalui regresi linear berganda, maka dapat disimpulkan bahwa $\mathrm{H}_{01}$ ditolak atau $\mathrm{H}_{\mathrm{a} 1}$ diterima, artinya secara 
parsial variabel jenjang pendidikan berpengaruh secara signifikan terhadap variabel penggunaan informasi akuntansi.

2. Berdasarkan hasil uji parsial (uji t) melalui regresi linear berganda, maka dapat disimpulkan bahwa $\mathrm{H} 02$ ditolak atau $\mathrm{Ha} 2$ diterima, artinya secara parsial variabel ukuran usaha berpengaruh secara signifikan terhadap variabel penggunaan informasi akuntansi.

3. Berdasarkan hasil uji parsial (uji t) melalui regresi linear berganda, maka dapat disimpulkan bahwa H03 ditolak atau Ha3 diterima,artinya secara parsial variabel lama usaha berpengaruh secara signifikan terhadap variabel penggunaan informasi akuntansi.

4. Berdasarkan hasil uji parsial (uji t) melalui regresi linear berganda, maka dapat disimpulkan bahwa HO4 ditolak atau Ha4 diterima,artinya secara parsial variabel masa memimpin perusahaan berpengaruh secara signifikan terhadap variabel penggunaan informasi akuntansi.

5. Berdasarkan hasi pengujian secara simultan (uji F) melalui regresi linear berganda, maka dapat disimpulkan bahwa $\mathrm{H} 05$ ditolak dan Ha5 diterima, artinya secara bersama-sama (secara parsial) variabel independen yaitu variabel jenjang pendidikan, ukuran usaha, lama usaha, dan masa memimpin perusahaan secara signifikan terhadap variabel dependen yaitu penggunaan informasi akuntansi.

\section{Saran}

1. Bagi pemerintah khususnya Dinas Koperasi dan UMKM Kabupaten Lombok Timur diharapkan dapat melakukan penyuluhan secara berkelanjutan kepada UMKM, agar UMKM semakin sadar akan pentingnya penyusunan laporan keuangan dan memberikan pelatihan pada UMKM dalam menyusun laporan keuangan berdasarkan kaidah-kaidah yang berlaku. Serta memberikan penyuluhan dan pelatihan sesuai bidang usaha UMKM agar UMKM lebih mengetahui perkembangan yang ada.

2. Bagi perusahaan UMKM yang menjadi objek dalam penelitian ini, harus lebih memahami dan menggunakan informasi akuntansi seperti informasi operasii manajemen dan khususnya untuk informasi akuntansi keuangan lebih diperhatikan lagi, penyediaan laporan keuangan mutlak harus disediakan apabila UMKM membutuhkan modal dan akan mengajukan kredit ke Bank. Perkembangan dan persaingan usaha yang sangat pesat memaksa para pemilik UMKM untuk mengembangkan usaha dan masalah permodalan sering menjadi kendala bagi para pemeilik UMKM. Dengan adanya informasi akuntansi yang baik diharapkan pengusaha UMKM dapat berkembang dan survive didalam persaingan bisnis yang yang sangat ketat. 
3. Diharapkan untuk peneliti selanjutnya tidak terpaku pada faktor dalam penelitian ini yaitu jenjang pendidikan, ukuran usaha, lama usaha, dan masa memimpin perusahaan. Namun peneliti selanjutnya diharapkan dapat menambah faktor-faktor lain yang mungkin dapat mempengaruhi penggunaan informasi akuntansi.

\section{Daftar Pustaka}

Andriani, Nita dan Zulliyati. 2015. Faktor-faktor yang memengaruhi penggunaan informasi akuntansi (studi pada UMKM kain tenun ikat troso jepara). Tesis Universitas Muria Kudus

Aris Budi Setyawan. 2012. Persepsi dan pemilik dan pengetahuan akuntansi selaku usaha kecil dan menengah atas penggunaan informasi akuntansi. Tesis Universitas Guna darma.

Belkaoui, Riahi Ahmed. 2011. Teori Akuntansi Buku 1. Jakarta: Salemba Empat.

Grace Tiana, Solovida. 2003. Analisis faktor-faktor yang mempengaruhi penyiapan dan penggunaan informasi akuntansi pada perusahaan kecil dan menengah dijawa tengah. Semarang : Magister Akuntan UNDIP.

Handayani. 2011. Faktor-faktor yang mempengaruhi penggunaan informasi akuntansi Usaha Kecil dan Menengah. Jurnal akuntansi. UNES Semarang.

Kementerian Koperasi dan UMKM. 2008. UU No. 20 Tahun 2008 Tentang UMKM. Jakarta.

Muhammad Wahyudi. 2009. Analisis faktor-faktor yang mempengaruhi penggunaan informasi akuntansi pada usaha kecil dan menengah (UKM) di Yogyakarta. Tesis Universitas Diponegoro.

Murniati. 2002. Analisis fakto-faktor yang mempengaruhi penyiapan dan penggunaan informasi akuntansi pada pengusaha kecil dan menengah di Jawa Tengah. Semarang. Universitas Diponegoro.

Sekaran, Uma. 2011. Metode Penelitian Untuk Bisnis. Jakarta: Salemba Empat

Sugiyono. 2012. Metode Penelitian Bisnis. Jakarta: CV. Alfabeta.

Tuti dan Dwijayanti. 2014. Faktor-Faktor Yng Mempengaruhi Pemahaman UMKM Dalam Penyusunan Laporan Keuangan Berdasarkan SAK ETAP. The 7th NCFB and Doctroral Colluiqium 2014. 